
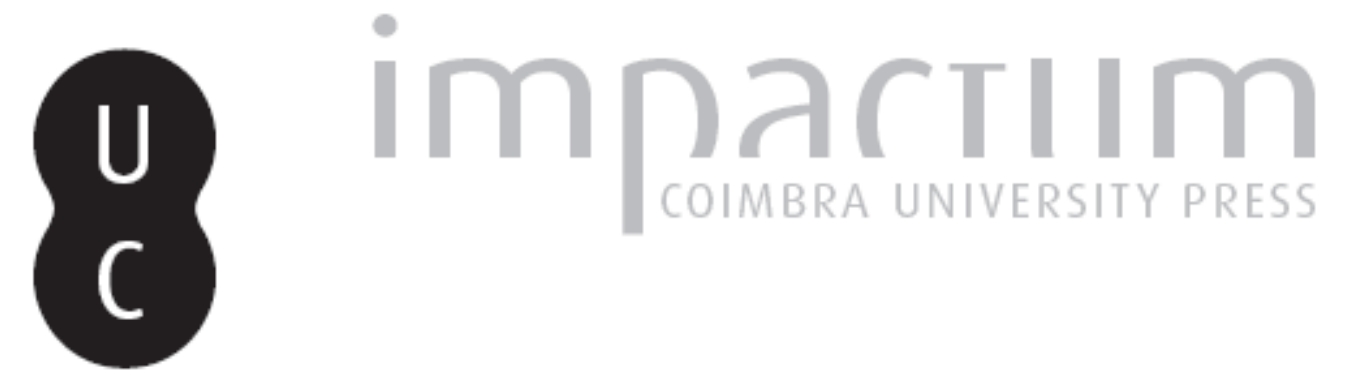

Jornalismo Radical: lições da Grécia

Autor(es): $\quad$ Siapera, Eugenia

Publicado por: Imprensa da Universidade de Coimbra

URL persistente: URI:http://hdl.handle.net/10316.2/43151

DOI: DOI:https://doi.org/10.14195/2183-6019_4_3

Accessed : $\quad$ 26-Apr-2023 06:28:21

A navegação consulta e descarregamento dos títulos inseridos nas Bibliotecas Digitais UC Digitalis, UC Pombalina e UC Impactum, pressupõem a aceitação plena e sem reservas dos Termos e Condições de Uso destas Bibliotecas Digitais, disponíveis em https://digitalis.uc.pt/pt-pt/termos.

Conforme exposto nos referidos Termos e Condições de Uso, o descarregamento de títulos de acesso restrito requer uma licença válida de autorização devendo o utilizador aceder ao(s) documento(s) a partir de um endereço de IP da instituição detentora da supramencionada licença.

Ao utilizador é apenas permitido o descarregamento para uso pessoal, pelo que o emprego do(s) título(s) descarregado(s) para outro fim, designadamente comercial, carece de autorização do respetivo autor ou editor da obra.

Na medida em que todas as obras da UC Digitalis se encontram protegidas pelo Código do Direito de Autor e Direitos Conexos e demais legislação aplicável, toda a cópia, parcial ou total, deste documento, nos casos em que é legalmente admitida, deverá conter ou fazer-se acompanhar por este aviso. 
revista de comunicação,

jornalismo e espaço público

$\angle$

Periodicidade

Semestral

Imprensa da Universidade de Coimbra Coimbra University Press

\section{mediapolis}

comunicação e transformações sociais

communication and social transformations 


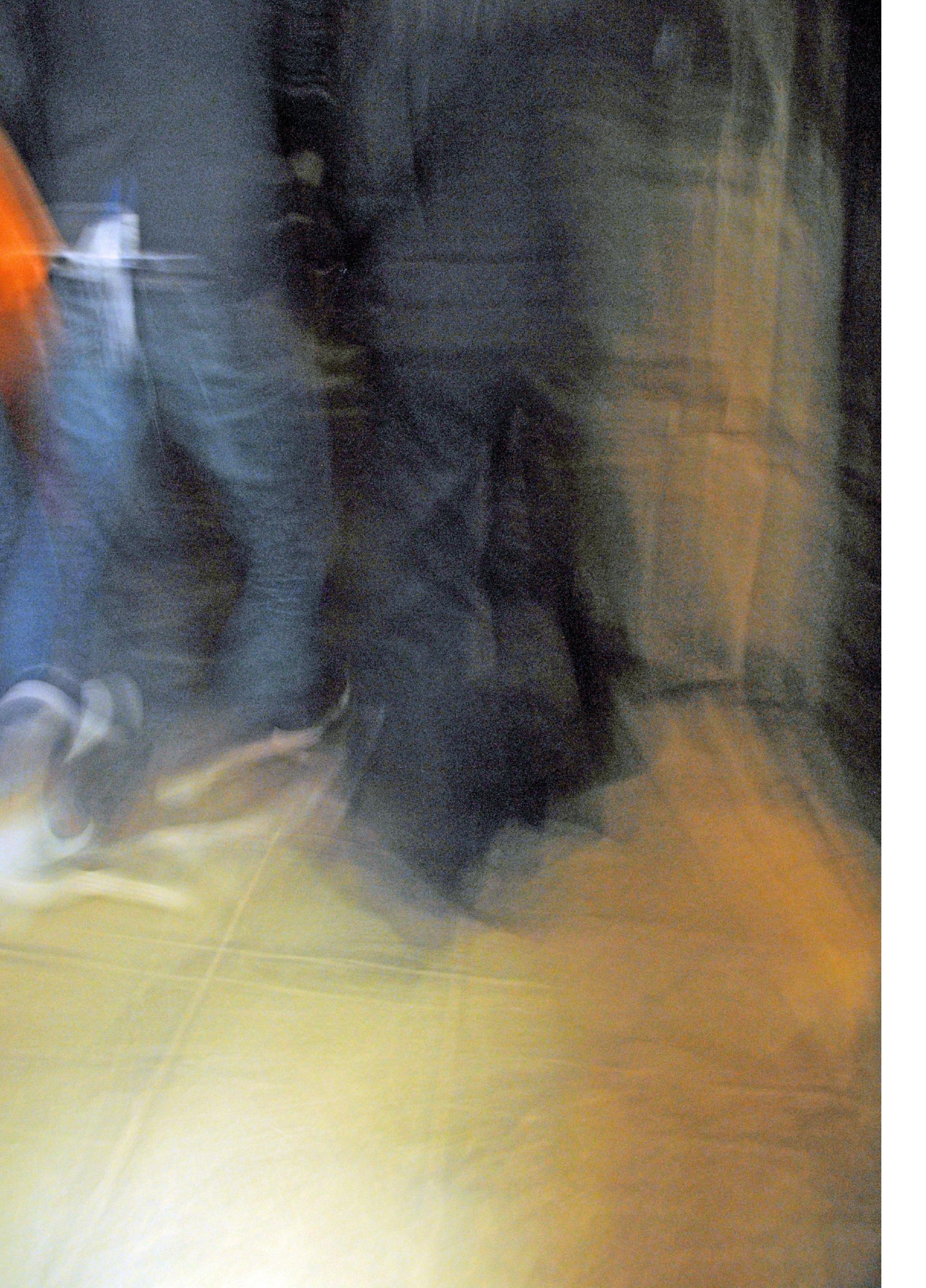




\title{
Jornalismo Radical: Lições da Grécia
}

\author{
Radical Journalism: Lessons from Greece
}

https://doi.org/10.14195/2183-6019_4_3

\section{Resumo}

Centrado no caso da Grécia, este texto vem traçar os contornos de um novo paradigma do jornalismo radical. Argumentamos que este novo paradigma é radical em cinco sentidos: em termos de sua organização, em termos de identidade de seus produtores, em termos de suas orientações face ao establishment político e à sociedade, em termos dos seus conteúdos, e em termos de sua relação com leitores e públicos. Tomados em conjunto, estes sentidos mostram um novo papel radical para o jornalismo, concentrado na abordagem das necessidades atuais de uma sociedade em crise. O papel político do jornalismo foi há muito tempo integrado numa compreensão gramsciana da hegemonia e no papel dos intelectuais que agitam e persuadem. $\mathrm{O}$ surgimento de um novo jornalismo radical em contexto de crise significa uma relação mais fundamental e orgânica do jornalismo com a sociedade, que requer mais do que agitação de suporte. Os jornalistas radicais não procuram liderar, agitar ou relatar desligados da sociedade. Em vez disso, este jornalismo nascido da crise e operando como crítica pode ser visto como um jornalismo de praxis ou de fazer: por isso, a ênfase é mais na construção ou restauração de relações sociais, em vez de legitimar as existentes como no caso do jornalismo liberal. Isso mostra um novo caminho e um papel político para o jornalismo, no qual ele se torna parte integrante da sociedade e em que está firmemente orientado para as necessidades sociais.

Palavras-chave: Jornalismo radical, crise, crítica, jornalismo liberal, Grécia.

\section{Abstract}

Focusing on the case of Greece, this chapter is tracing the contours of a new paradigm of radical journalism. We argue that this new paradigm is radical in five ways: in terms of its organization, in terms of the identities of its producers, in terms of its orientations vis-à-vis the political establishment and the society, in terms of its contents, and in terms of its relationship with readers and publics. Taken together these show a new radical role for journalism, focusing on addressing the present needs of a society in crisis. Journalism's political role was far too long annexed to a Gramscian understanding of hegemony and the role of intellectuals who agitate and persuade. The rise of a new radical journalism in conditions of crisis signifies a more fundamental and organic relationship of journalism to society that requires more than agit prop. Radical journalists are not seeking to lead or to agitate or to report disconnected from society. Rather, this journalism born of the crisis and operating as critique can be seen as a journalism of praxis or doing: this is why the emphasis is more on building or restoring social relationships, rather than in legitimising existing ones as in the case of liberal journalism. This shows a new avenue and political role for journalism, in which it becomes an integral part of society and in which it is firmly oriented towards social needs.

Keywords: Radical journalism, crisis, critique, liberal journalism, Greece. 


\section{Introdução}

Um dos mais antigos e históricos títulos de jornais da Grécia é o Rizospastis - O Radical - o jornal do Partido Comunista Grego. O Rizospastis foi fundado em 1916 e a sua história acompanhou a turbulenta história da Grécia ao longo do último século, com longos períodos de proibições e perseguições. O Rizospastis é publicado de modo gratuito como jornal diário desde 1974, oferecendo uma alternativa e uma perspetiva frequentemente radical das notícias, apoiando de forma inequívoca os sindicatos e as lutas dos trabalhadores contra o patronato. No entanto, nos últimos anos, o Rizospastis e a sua empresa mãe, a Typoekdotiki, detidos e geridos pelo Partido Comunista Grego, viram-se envolvidos num conjunto de ações e práticas que foram nocivas para os seus próprios trabalhadores: desde 2010 que se registaram quase 230 despedimentos, a maioria deles sem compensação, os trabalhadores não receberam e, pior ainda, as contribuições da entidade empregadora para o seguro social dos seus trabalhadores também não foram liquidadas, fazendo com que os trabalhadores despedidos não se qualifiquem para receber subsídio de desemprego. O Partido Comunista está a desinvestir do sector dos meios de comunicação, vendendo os seus ativos e despedindo os trabalhadores em simultâneo. Enquanto o Rizospastis, O Radical, continua a ser publicado diariamente com a mistura de notícias e agitprop típica do Partido Comunista, ao fim ao cabo os seus donos, o PC, operam de modo semelhante a qualquer empresa neoliberal.

É do conhecimento geral que o jornalismo na Grécia está a sofrer uma intensa crise aos mais variados níveis. A classificação da Media Freedom House reporta um declínio de 21 pontos no seu sistema de classificação nos últimos 5 anos, de longe o mais acentuado em todo o mundo (Media Freedom House, 2015). Os meios de comunicação social na Grécia sofrem de uma interferência crónica ao nível político e comercial e a sua confiança e credibilidade está gravemente comprometida, como demonstra o Eurobarómetro (2014), onde 84\% expressam não confiar na televisão (comparativamente à média de $48 \%$ na $\mathrm{UE}$ ), de longe a mais baixa na UE, e $74 \%$ referem não confiar nos jornais (média da UE de 53\%), apenas ultrapassado pelo Reino Unido. Os jornalistas, conforme descobrimos (Siapera et al., 2014), são os primeiros a queixar-se da situação, apontando o dedo às oligarquias dos meios de comunicação, ao panorama político confuso e ao estado grego clientelista. Num outro estudo, os jornalistas gregos referem interferências diretas e indiretas por parte dos donos dos meios de comunicação e do governo (Siapera, 2015), daí decorrendo um jornalismo comprometido e "parcialmente livre". Apesar disso, nos últimos 5 anos assistimos a uma série de ações, greves, paralisações, petições e outros, com o objetivo de levar esses meios noticiosos a readmitir os jornalistas despedidos. Neste contexto, a pergunta óbvia é por que razão quereriam os jornalistas ser contratados por meios de comunicação corruptos? Como o bem conhecido jornalista e blogger Pitsirikos refere, deveríamos estar a falar sobre "jornalistas livres" em vez de jornalistas "despedidos" (Pitsirikos, 2012). Será o papel do sindicalismo aqui ambíguo ao ponto de ser conservador?

Em terceiro lugar, o panorama dos meios de comunicação na Grécia assistiu à entrada de dois novos atores dinâmicos: 


\section{Introduction}

One of the longest and most historical newspaper titles in Greece is Rizospastis - The Radical - the newspaper of the Communist Party of Greece. Rizospastis was founded in 1916 and its history has followed the turbulent history of Greece throughout the previous century, with long periods of prohibition and prosecution. Rizospastis has been publishing freely as a daily newspaper since 1974, offering an alternative and often radical view of the news, unequivocally supporting unions and workers' struggles against employers. However, in the last years or so, Rizospastis and its parent company Typoekdotiki, owned and managed by the Communist Party of Greece, have been involved in a series of actions on and practices that have been detrimental to their own workers: since 2010 there have been almost 230 lay-offs, often with no compensation, workers have not been paid, and even worse employers' insurance contributions for their workers have not been paid either with the result that laid-off workers are not eligible for unemployment benefit. The Communist Party is divesting from the media field, selling off its assets, and getting rid of workers at the same time. Yet Rizospastis, The Radical, is still published daily with the Communist Party's mixture of news and agitprop, while the all the while its owners, the $\mathrm{CP}$, operate in the same way as any neoliberal company.

It is well known that journalism in Greece is undergoing an intense crisis at all levels. The Media Freedom House ratings report a decline of 21 points in their rating system in the last 5 years, by far the steepest across the world (Media Freedom House, 2015). News media in Greece suffer from chronic political and commercial interference, and their trust and credibility is severely compromised, as shown by the Eurobarometer (2014), where $84 \%$ do not trust television (compared to $48 \% \mathrm{EU}$ average), by far the lowest in the $\mathrm{EU}$, and $74 \%$ do not trust newspapers (53\% EU average), second only to the UK. Journalists, as we found out (Siapera et al., 2014) are the first to complain about the situation, pointing the finger to media oligarchs, a confused policy landscape and the clientalist Greek state. In another study, Greek journalists reported both direct and indirect interference by media owners and the government (Siapera, 2015),resulting in a compromised and 'partially free' journalism. Yet in the last 5 years we have seen a series of actions, strikes, work-stoppages, petitions etc., aimed at getting these problematic news media to re-hire laid off journalists. In this context, the obvious question is, why would journalists want to be employed by corrupt media? As the well-known blogger-journalist Pitsirikos put it, we should be talking about 'free journalists' rather than 'laid off' journalists (Pitsirikos, 2012). Is the role of syndicalism here ambiguous to the point of being conservative?

Thirdly, the media landscape in Greece has seen two dynamic new media players entering: Efimerida Syntakton - the Editors' Newspaper - which is a cooperative print and online news medium run exclusively by its workers, including journalists, marketing and sales people, technicians and all those needed to pint and run a newspaper and online 
O Efimerida Syntakton - o Jornal do Editor - um título no âmbito da imprensa cooperativa e notícias online exclusivamente gerido pelos seus trabalhadores, incluindo jornalistas, pessoas de marketing e vendas, técnicos e todos os demais profissionais necessários para produzir um jornal em papel e online. O Efsyn tem tido grande sucesso, rapidamente ocupando o segundo lugar na classificação dos semanários nacionais. Em paralelo, o The Press Project constitui uma nova iniciativa jornalística, nascida na crise, produzindo "jornalismo livre" (termo deles) e procurando sobreviver fora dos interesses estabelecidos. Em entrevistas com jornalistas que trabalham nestas duas iniciativas encontrámos um dilema crucial: Aceitariam anúncios de bancos? Se sim, qual seria o impacto disto no seu jornalismo? Será que isso irá criar algum grau de dependência e comprometer a sua independência? Ou o imperativo de sobrevivência sobrepõe-se a tudo?

Estes três exemplos ilustram algumas das fundamentais tensões no jornalismo e no jornalismo radical no contexto da prologada crise capitalista e também estão ligados às funções e raison d'etre do jornalismo (radical).
Poderá um meio de comunicação que se pretende radical funcionar como uma empresa neoliberal? Os jornalistas em situação precária são jornalistas livres? $\mathrm{O}$ que pode o jornalismo radical fazer para sobreviver enquanto jornalismo radical? Ao longo das próximas linhas pretendemos desenvolver a seguinte linha de argumentação: no contexto de uma prolongada crise capitalista e num contexto político de pós-democracia pode observar-se a ascensão de um novo paradigma no jornalismo que é radical em cinco vertentes: em termos da sua organização, em termos das identidades dos seus produtores, em termos das suas orientações em face do poder político estabelecido e da sociedade, em termos dos seus conteúdos e em termos da sua relação com os leitores e públicos. Não pretendemos sugerir que se trata de um novo jornalismo em pleno florescimento e já estabelecido, preferimos antes delinear as suas sementes, que já são suficientes para perspetivar os contornos básicos que permitem conceber um novo jornalismo radical. $\mathrm{Na}$ senda deste argumento, começamos por debater o jornalismo radical e alternativo na literatura, antes de passarmos a apresentar os contornos do novo jornalismo radical que está a emergir na Grécia, mas que se espera não seja limitado a este país. Concluímos, finalmente, com uma discussão - essencialmente especulativa - sobre o que este jornalismo nos pode ensinar em matéria de organização e autonomização social.

\section{Conceitos e Conceções de Jornalismo Radical}

A publicação fundamental sobre os meios radicais é a obra Radical Media de John Downing (1984; 2001: ix-xi) onde este descreve os meios radicais alternativos com base em dez características que os definem: que sejam não apenas alternativos como também radicais; que possam ser progressivos mas também regressivos, como os meios fascistas; que possam pertencer a comunidades específicas (por exemplo comunidades étnicas ou religiosas); que o seu radicalismo possa variar em grau e intensidade; que possam existir de forma polarizada e polarizante especialmente em regimes não liberais; que possam ser encontrados numa grande variedade de formatos; que sejam em última instância 
medium. Efsyn has been extremely successful, jumping into the second place in national weekly circulation rankings. In parallel, The Press Project constitutes a new journalistic initiative, born in the crisis, producing 'free journalism' (their term) and seeking to survive outside the known interests. In interviews with journalists working in these two initiatives, we came across a crucial dilemma: Would they accept adverts from banks? If so, what would be the impact of this on their journalism? Would it create a dependency and compromise their freedom? Or is the survival imperative overshadowing everything?

These three examples illustrate some fundamental tensions in journalism and in radical journalism in the context of protracted capitalist crisis, and they are also linked to the functions and raison d'etre of (radical) journalism. Can a radical media operate as a neoliberal company? Are precarious journalists freed journalists? What can radical journalism do to survive as radical journalism? In what follows, we want to pursue the following line of argument: that in the context of protracted capitalist crisis and in a political context of post-democracy we can observe the rise of a new paradigm of journalism that is radical in five ways: in terms of its organization, in terms of the identities of its producers, in terms of its orientations vis-à-vis the political establishment and the society, in terms of its contents, and in terms of its relationship with readers and publics. we do not mean to suggest that this is an already fully blossoming and established new journalism. Rather, we can just about make out the grains of this, but which are enough to provide the basic contours for conceiving a new radical journalism. In pursuing this argument, we begin with a discussion of radical and alternative journalism in the literature, before moving on to sketch the contours of the new radical journalism that is emerging in Greece, but which hopefully is not limited to Greece. Finally, we conclude with a-mostly speculative - discussion of what this journalism can teach us for social organization and autonomization.

\section{Concepts and Conceptions of Radical Journalism}

The pivotal publication on radical media is John Downing's (1984; 2001: ix-xi) Radical Media where he describes radical alternative media in terms of ten defining characteristics: that they are not only alternative but also radical; that they can be progressive but also regressive, such as fascist media; that they can belong to specific communities (for example ethnic or religious communities); that their radicalism can vary in degree and intensity; that they can exist in a polarized and polarizing fashion especially in illiberal regimes; that they can be found in a great variety of formats; that ultimately, they are radical because they break somebody's rules, although not all of them and not in every respect; that they are typically under-funded, small-scale and unnoticed; that they serve two purposes: to express opposition and to build support, solidarity and networking against certain policies or the very status quo; finally, they tend to be more democratically 
radicais porque quebram as regras de alguém, apesar de não todas nem em todas as vertentes; que disponham tipicamente de fundos reduzidos, sejam de pequena escala e passem despercebidos; que sirvam dois propósitos: expressar oposição e constituir meios de apoio, solidariedade e estabelecimento de redes contra determinadas políticas ou mesmo contra a situação estabelecida (status quo); finalmente, que tenham tendência para ser mais democraticamente organizados e geridos do que os meios convencionais.

Esta lista abrangente contribui fortemente para o debate de questões que incluem as diferenças entre os meios radicais, alternativos e convencionais. Adicionalmente, uma questão chave relativamente aos meios radicais tem sido a sua grande diversidade em termos de forma, conteúdo e posicionamentos no que toca às estruturas de poder. A lista das suas caraterísticas fundamentais vai no sentido de capturar esta diversidade sem postular uma definição exclusiva e definitiva do que é e não é o jornalismo radical. $\mathrm{O}$ resultado é um conjunto de práticas emergentes que é fluído e dinâmico mas que, na sua maioria, está confinado e é definido pela oposição às estruturas do poder estabelecido. Por outro lado, Downing entende os meios radicais como os meios dos movimentos sociais, parte integrante e constitutiva de uma mobilização mais alargada contra estruturas de poder estabelecidas e injustas. É especificamente a sua posição num triângulo de movimentos sociais, meios de comunicação e a esfera pública mais alargada que os torna radicais, argumenta Downing, apesar de ser cuidadoso ao referir que nem todos os meios radicais navegam na onda dos movimentos sociais: alguns podem estar "pacientemente atentos às questões e especialmente a desenvolver novos temas" (p. 31) mesmo na ausência de mobilização social para esses temas. O triângulo constituído por movimentos sociais, meios de comunicação e a esfera pública é operacionalizado através de redes de comunicação interpessoal, que espalham e amplificam a voz e o alcance dos meios radicais.

Enquanto os meios radicais ocupam esta posição na estrutura abrangente da comunicação política-público, exercendo mediação entre o movimento social e a esfera pública alargada, a sua organização e funções podem ser duplas. Os meios radicais podem ter uma função política Leninista, na qual se persegue a mudança social e política através de um modo baseado em agitprop de agitação e propaganda; estes meios estão tipicamente associados a uma organização hierárquica. Em segundo lugar, os meios radicais baseiam-se num modo de autogestão, no qual existe discussão e debate sobre o que publicar e de que modo e cuja principal função política é prefigurativa ou, por outras palavras, para praticar e viver de forma socialista no presente como "contínua realização da liberdade" no aqui e no agora (Wieck, 1979, em Downing et al., 2001: 71). É este segundo modelo que Downing considera mais em linha com uma transformação radical da sociedade na prossecução da justiça social e o contributo essencial é que os meios radicais ponham em prática aquilo que apregoam.

A análise de Downing tem ecos na obra de Rodriguez (2001), cujo estudo dos meios alternativos da Colômbia e Nicarágua aponta para as formas nas quais o significado e ganhos desses meios não se prenderam tanto com o 
organized and managed than conventional media.

This comprehensive list goes a long way towards addressing questions including the differences between radical, alternative and mainstream media. Additionally, a key issue regarding radical media has been their great diversity in forms, contents, and positions vis-à-vis power structures. The list of their defining characteristics goes some way towards capturing this diversity without positing an exclusive and definitive definition of what is and what isn't radical journalism. The result is an emergent, fluid dynamic set of practices, but which for the most part is confined in, and defined by, opposition to established structures of power. On the other hand, Downing understands radical media as the media of social movements, part and parcel of broader social mobilizations against established and unfair structures of power. It is specifically their position in a triangle of social movements, media and the broader public sphere that makes them radical, argues Downing, although he is carefully noting that not all radical media ride the wave of social movements: some may be "patiently issues alive and especially developing new themes" (p. 31) even in the absence of social mobilization on these themes. The triangle of social movements, media and the public sphere is made operational through interpersonal communication networks, which spread and amplify the voice and reach of radical media.

While radical media occupy this position in the broader structure of political-public communication, mediating between social movement and the broader public sphere, their organization and functions can be two-fold. Radical media can have a Leninist political function, in which social and political change is pursued through an agit-prop mode of agitating and propagandizing; these media are typically associated with a hierarchical organization. Secondly, radical media can be based on a self-management mode, wherein there is discussion and debate on what to publish and how, and where their main political function is prefigurative, or in other words to practice and live in a socialist manner in the present, as the "continuous realization of freedom" in the here and now (Wieck, 1979, in Downing et al., 2001: 71). It is the second model that Downing finds more in line with a radical transformation of society in pursuit of social justice, and the crucial insight is that radical media practice what they preach.

Downing's analysis is echoed in work by Rodriguez (2001), whose study of Colombian and Nicaraguan alternative media points to the ways in which the significance and gains of these media were not so much that they helped bring forward socialism, but that they changed the very identities of those involved in them. Rodriguez relies on Chantal Mouffe's (1992) understanding of the political as a space for contestation and resignification, and on the work of Paulo Freire on critical pedagogy. For Rodriguez, radical media produced by citizens first and foremost contribute to the political education of these citizens, and through that to political change. For both Downing and Rodriguez, the key to understanding radical media is to understand not only or even primarily their contents as radical/alternative narratives, but the processes by which these are produced, as these form part of the realization of a more egalitarian politics in practice. 
apoio à introdução do socialismo mas mais com a alteração da própria identidade daqueles que neles estavam envolvidos. Rodriguez baseia-se no entendimento de Chantal Mouffe (1992) relativamente ao político enquanto espaço de contestação e ressignificação, bem como no trabalho de Paulo Freire em matéria de pedagogia crítica. Para Rodriguez os meios radicais produzidos por cidadãos contribuem em primeiro lugar e acima de tudo para a educação política desses mesmos cidadãos e, através disso, para a mudança política. Tanto para Downing como para Rodriguez, a chave para a compreensão dos meios radicais é entender não apenas nem mesmo principalmente os seus conteúdos como narrativas radicais/alternativas, mas antes os processos através dos quais estes são produzidos, uma vez que fazem parte da concretização de uma política mais igualitária na prática.

A explosão de meios cidadãos e radicais no seguimento do advento da internet e mais ainda dos meios sociais levou a uma explosão associada de publicações em meios alternativos, jornalismo cidadão, blogues de cidadãos e jornalísticos entre outros. Em linha com Rodriguez, Atton (2002),
Couldry (2000) e Couldry and Curran (2003) descrevem meios alternativos como práticas de meios de comunicação baseadas nos cidadãos e outros meios à margem (Rodriguez, 2014). Couldry $(2000 ; 2002)$ entende os meios alternativos como práticas profissionais desafiantes e poder mediático, precisamente devido a reconhecerem-nas como práticas convencionais e profissionalizadas e não a verdade ou realidade absoluta, consequentemente desmistificando-as. Atton (2002) argumenta que o jornalismo alternativo como produção amadora do jornalismo deve ser levado a sério tanto na vertente de processo como de produto. Atton regressa ao conteúdo e forma como essencial, apontando para as formas através das quais eles ajudam a transformar as relações sociais pelo fornecimento de novos meios discursivos e estéticos de apreensão da realidade. Uma das formas para o fazer inclui a colocação de vozes populares e da comunidade no meio em vez de depender de fontes noticiosas especializadas ou oficiais. Esta inclusão de fontes não especializadas e enfoque nos problemas sociais locais pode levar ao estabelecimento de redes de "repórteres nativos" (Atton, 2002) em vez dos típicos ativistas de esquerda associados aos projetos de meios radicais. O conjunto de artigos na obra de Couldry and Curran (2003) apresenta os meios e esforços de comunicação alternativos como contestação direta do poder mediático; alguns meios provêm de fontes não profissionais, movimentos sociais, redes comunicativas populares emergentes mas todas se movem no sentido de contestar o poder dos meios de comunicação convencionais e a sua determinação de visibilidade e mérito.

Bailey et al. (2007) desenvolve uma taxonomia dos meios alternativos, onde se incluem: (i) meios comunitários que servem comunidades específicas, (ii) meios alternativos que desafiam a hegemonia dos meios convencionais, (iii) meios populares baseados na sociedade civil e (iv) meios rizomáticos que se movem entre as fronteiras da sociedade civil, o mercado e o estado, e que são entendidos por Bailey et al. como fluídos e contingentes e como aspetos contestantes e "desterritorializados" do mercado e do estado, bem como de identidades e práticas sociais rigidificadas.

Para resumir, este corpo de investigação sublinhou o papel e função 
The explosion of citizen and radical media following the rise of the internet and more so of social media led to an associated explosion of publications on alternative media, citizen journalism, citizen and j-blogs and so on. Alongside Rodriguez, Atton (2002), Couldry (2000) and Couldry and Curran (2003) describe alternative media as citizen-based media practices and other media-at-the-margins (Rodriguez, 2014). Couldry (2000; 2002) understands alternative media as challenging professional practices and media power, precisely because they recognize them as mainstream, professionalized practices and not the absolute truth or reality, thereby de-mystifying them. Atton (2002) argues that alternative journalism as amateur production of journalism must be taken seriously both as process and as product. Atton returns to contents and forms as crucial, pointing to the ways in which they help transform social relations through providing new discursive and aesthetic means for apprehending reality. One of the ways this is done includes placing community and grassroots voices in the middle rather than relying on expert or official news sources - this inclusiveness of non-expert sources and focus on local social problems may lead to networks of 'native reporters' (Atton, 2002) rather than the typical left wing activists associated with radical media projects. The collection of essays in Couldry and Curran (2003) posit alternative media and communication efforts as direct contestations of media power; some media come from non-professional sources, from social movements, from grassroots emerging communicative networks but they all move towards contesting the power of the mainstream media and their determination of visibility and worthiness.

Bailey et al. (2007) develop a taxonomy of alternative media; these include: (i) community media serving specific communities, (ii) alternative media challenging mainstream media hegemony, (iii) civil society-based grassroots media and (iv) rhizomatic media that move between the borders of civil society, the market and the state, and which Bailey et al. understand as fluid and contingent, and as contesting and 'derritorializing' aspects of the market and the state as well as rigidified identities and social practices.
To sum up, this body of research has highlighted the role and political function of alternative media as challenging the mainstream and seeking social and political change. They do this both by developing alternative narratives, contents and aesthetic forms and through their non-hierarchical forms of organization which prefigure a socialist social organization. They are small scale, have a limited reach, and they are definitely non-professional, citizen or activist based initiatives. While therefore extremely attractive in offering a glimpse of what could be, these media seem to me to be destined to fail because as soon as actually scale, professionalize in the sense that they create norms and a specific know-how, they revert to the mainstream and are therefore lost. So the question is, can radical and alternative journalism ever be large scale and professional and still seek socio-political change? Can journalism be organized as a radical collective? The current argument is that yes it can be and do all this. The next section will explain how and why this is happening in the case of Greece. 
política dos meios alternativos enquanto desafiante do convencional e catalisador da mudança social e política. Estes meios fazem-no através do desenvolvimento de narrativas, conteúdos e formas estéticas alternativas, bem como através das suas formas não hierárquicas de organização que prefiguram uma organização social socialista. Tratam-se de meios de pequena escala, com cobertura limitada e são definitivamente iniciativas não profissionais, de cidadãos ou ativistas. Apesar da sua extrema atração por oferecerem um vislumbre do que poderia ser, estes meios parecem-me destinados ao fracasso porque assim que atinjam escala e se profissionalizem, no sentido de que estabeleçam normas e conhecimentos específicos, convertem-se em meios convencionais e portanto perder-se-ão. Assim, a questão que se põe é se o jornalismo radical e alternativo poderá alguma vez ser de larga escala e profissional procurando, simultaneamente, a mudança sociopolítica? Poderá o jornalismo ser organizado como coletivo radical? $\mathrm{O}$ argumento atual é de que isso é possível. Na próxima seção explica-se como e por que é que isso tem vindo a acontecer no caso da Grécia.

\section{Jornalismo Radical na Grécia}

Numa revisão de Couldry and Curran (2003), Natalie Fenton (2005) argumenta que tanto os meios alternativos como as contestações do poder mediático e os próprios meios convencionais pertencem à mesma ordem de economia política dos sistemas de comunicação. Qualquer contestação é estruturada por este contexto e tem lugar dentro dele. A economia política dos meios de comunicação e jornalismo envolve uma concentração demasiado familiar de títulos de publicações, integração vertical e horizontal, a neoliberalização da produção, com fusões e desmembramento fraudulento dos ativos de sociedades, despedimentos e encerramentos e com mais contratos e trabalhadores em situação precária. Também esta é a história dos meios de comunicação na Grécia (ver Siapera et al., 2015). Mas este foi apenas o início.

A história do jornalismo radical contemporâneo na Grécia começou de facto com os despedimentos e encerramentos de títulos da imprensa. Não existem registos de quantos jornalistas perderam o emprego durante os anos de crise, mas o anterior secretário de estado do principal sindicato de jornalistas de Atenas estima que cerca de $30 \%$ dos seus membros estão desempregados (Trimis, 2012). Mas isto é apenas a ponta do iceberg, uma vez que existe uma enorme quantidade de jovens jornalistas que nunca tiveram sequer a oportunidade de se tornar membros do sindicato, pois nunca tiveram um contrato de trabalho na imprensa ou meio de difusão. Todo o campo do jornalismo tem enfrentado e continua a enfrentar uma disrupção em massa reflexo da ascensão do novo paradigma tecnológico social, por um lado, e pela crise da dívida, por outro. O mercado da publicidade está em queda livre: a despesa com publicidade em jornais e revistas ascendia a 250 milhões de euros em 2008, mas em 2015 tinha-se reduzido para 102 milhões de euros (Statista, 2016). Para além disso, as audiências na Grécia reportam tipicamente níveis muito baixos de confiança nos meios de comunicação: em 2015, $80 \%$ afirmavam não confiar nas notícias da televisão comparativamente à média da União Europeia de 47\%, enquanto 


\section{So the question}

is, can radical

and alternative

journalism ever

be large scale and

professional and

still seek socio-

-political change?

\section{Radical Journalism in Greece}

In a review of Couldry and Curran (2003), Natalie Fenton (2005) makes the point that both alternative media and contestations of media power and the mainstream media themselves belong to the same order of the political economy of communication systems. Any contestation is structured by and occurs within this context. The political economy of the media and journalism involves an all-too familiar concentration of media titles, vertical and horizontal integration, the neoliberalization of production, with mergers and asset stripping, layoffs and closures, and with more contract and precarious workers. This has been the media story in Greece too (see Siapera et al., 2015). But this was only the beginning.

The story of contemporary radical journalism in Greece in fact begins with the layoffs and closures of media titles. There are no records of how many journalists lost their job in the years of the crisis, but the former secretary of the main union of journalists in Athens estimates that about $30 \%$ of their members are unemployed (Trimis, 2012). But this is likely to be just the tip of the iceberg, as there is a whole layer of younger journalists who have never been able to become union members, as they never had a contracted job in print or broadcast media. The whole field of journalism has faced and is still facing massive disruption brought about by the rise of the new technological paradigm on the one hand, and by the debt crisis on the other. The advertising market is in free fall: advertising expenditure in newspapers and magazines amounted to $€ 250$ million in 2008 , but by 2015 this had fallen to $€ 102$ million (Statista, 2016). Moreover, audiences in Greece typically report very low levels of trust in the media: in 2015, $80 \%$ reported that they do not trust television news compared to the $\mathrm{EU}$ average of $47 \%$, while $65 \%$ reported that they do not trust newspapers, compared to the $50 \%$ of the EU average (Eurobarometer, 2015). These reflect a clear disconnect and a growing chasm between politicians, journalists and publics.

In addition to decreasing revenues and low levels of trust, journalism in Greece is facing another kind of crisis that stems from political and power shifts associated with the rise of post democracy. Post democracy according 
$65 \%$ afirmavam que não confiavam nos jornais, comparativamente aos $50 \%$ da média da UE (Eurobarómetro, 2015). Estes números refletem uma clara dissociação e um crescente fosso entre os políticos, os jornalistas e o público.

Para além do decréscimo das receitas e baixos níveis de confiança, o jornalismo na Grécia está a enfrentar um outro tipo de crise que decorre das alterações políticas e de poder associadas à ascensão da pós-democracia. De acordo com Colin Crouch (2004; 2011) pós-democracia refere-se a uma situação política em que a maior parte das decisões são tomadas fora dos países e os governos nacionais são meros executores dessas decisões. Todos os adornos da democracia estão presentes: parlamentos, eleições, referendos, tribunais, poder judicial e outros, mas existem enquanto formas vazias de conteúdo, uma vez que a verdadeira tomada de decisão política deixou de estar nas mãos dos governos nacionais.

Em nenhum outro lugar isto é tão claro como na Grécia: a aliança de esquerda Syriza foi eleita em janeiro de 2015 com o mandato de contestar as políticas de austeridade e as privatizações obrigatórias impostas pela Troika (UE, BCE e FMI). Este mandato foi novamente validado através de um referendo em julho de 2015 no qual uma maioria retumbante de $62 \%$ votou a favor da rejeição de qualquer acordo ou novo resgate financeiro por parte da Troika. Mesmo assim, o governo de coligação do Syriza ignorou de modo flagrante os resultados da eleição e do referendo e assinou um novo resgate financeiro escassos dias após o referendo de julho de 2015. O atual acordo entregou formalmente o poder a um "Grupo de Trabalho" da UE encarregue de supervisionar a sua implementação, incluindo as partes do acordo relativas à privatização que carecem de aprovação do parlamento.

Este contexto pós-democrático não é apenas politicamente intolerável, mas também acaba por criar uma situação insustentável para o jornalismo. Três das principais funções do jornalismo prendem-se com os papéis desempenhados ao nível de guardião, prestação de informação e fórum de debate público (Kovach and Rosenstiel, 2001). No entanto, o papel de guardião pressupõe que os decisores políticos sejam responsáveis perante as pessoas que os elegeram. Na pós-democracia não é este de todo o caso: os governos e os decisores políticos deixaram de ser responsáveis perante os eleitorados nacionais, pelo menos foi o que aconteceu no caso da Grécia. Um segundo papel do jornalismo tradicional sempre foi a prestação de informação precisa e "objetiva" para que a população possa tomar decisões racionais e informadas na altura de votar. Mas uma vez que o eleitorado e os seus desejos são clara e flagrantemente ignorados, este papel também deixa de ter significado. Em qualquer dos casos, a maior parte dos meios de comunicação convencionais na Grécia já se tinham tornado muito antes apologistas das políticas de austeridade neoliberal impostas à Grécia (Pleios, 2013; Poulikadakos, 2013) pelo que já não estavam a cumprir o seu mandato ao abrigo das normas do jornalismo liberal.

Esta situação criou um profundo fosso ou dissociação entre o jornalismo convencional e o público. Mas este fosso também criou uma abertura para que algo novo pudesse emergir. Foi assim que um novo tipo de 
to Colin Crouch $(2004 ; 2011)$ refers to political situation whereby most decision making takes place elsewhere and national governments are merely the enforcers of these decisions. The trappings of democracy are all there, parliaments, elections, referenda, the courts and the judiciary and so on, but they exist as empty forms, as the actual political decision making is no longer down to national governments.

Nowhere is this clearer than in Greece: the left alliance Syriza was elected in January 2015 with the remit to contest austerity policies and the compulsory privatisations imposed by the Troika (EU, ECB and IMF). This remit was further validated through a referendum in July 2015 in which a resounding majority of $62^{\wedge}$ voted to reject any agreement and any further bailout from the Troika. Yet, the Syriza coalition government blatantly ignored the results of both the election and the referendum and signed a further bailout agreement just days after the July 2015 referendum. The current agreement has formally surrendered power to an EU 'Task Force', charged with overseeing the implementation of the agreement, including those parts of the agreement concerning privatisation that have to be approved by the parliament.

This post-democratic context is not only politically intolerable. It further creates an impossible situation for journalism. Three of the typical functions of journalism are the role of watchdog, information provide and public forum (Kovach and Rosenstiel, 2001). However, the watchdog role presupposed that political decision makers are accountable to the people who voted for them. But in post democracy this is not the case at all: neither governments nor political decisions makers are accountable to national electorates any more - at least not in the case of Greece. A second role for traditional journalism has been to provide accurate and 'objective' information so that people can make rational and informed decisions when voting. But since the electorate and its wishes are clearly and blatantly ignored, this role has no meaning either. In any case, most mainstream media in Greece had long before become apologists for the neoliberal austerity policies imposed on Greece (Pleios, 2013; Poulikadakos, 2013) so that they were not fulfilling their remit under the norms of liberal journalism.

This situation had created a deep chasm or disconnect between mainstream journalism and the public. But this chasm has also created an opening for something new to emerge. This is where a new kind of radical journalism has emerged. The remainder of this paper will sketch the contours of this new form of radical journalism by looking at four levels: (i) the structural level, looking at funding and newsroom organisation; (ii) the substantive level, looking at contents and themes; (iii) the subjective level looking at journalistic identities; and (iv) the relational level, looking at the new relationships built between publics and journalism. These discussions are based on 30 in depth interviews with journalists and editors and through an analysis of their websites. All materials were collected in the period between July 2013 to August 2015. The media involved were: The Press Project, Efimerida Syntakton (Efsyn), Flash FM, Alterthess, The Cricket, Infowar, ErtOpen, Radiobubble, PressPublica, iKollect and Omnia TV. Separately, not all of these fulfil the remit for an alternative radical journalism; collectively however, they are suggestive of the creation of a new field of journalism in Greece that has the grains of a truly radical project. 
jornalismo radical surgiu. Ao longo da parte final deste artigo iremos traçar os contornos desta nova forma de jornalismo radical analisando quatro vertentes: (i) ao nível estrutural, analisando o financiamento e a organização da redação; (ii) ao nível substantivo, analisando os conteúdos e temas; (iii) ao nível subjetivo, analisando as identidades jornalísticas; e (iv) ao nível relacional, analisando as novas relações criadas entre os diferentes públicos e o jornalismo. Estas discussões baseiam-se em 30 entrevistas aprofundadas com jornalistas e editores e na análise das suas páginas na internet. Todos os materiais foram recolhidos entre julho de 2013 e agosto de 2015. Os meios de comunicação envolvidos foram: The Press Project, Efimerida Syntakton (Efsyn), Flash FM, Alterthess, The Cricket, Infowar, ErtOpen, Radiobubble, PressPublica, iKollect e Omnia TV. Separadamente nem todos eles cumprem os desígnios de jornalismo radical alternativo, mas coletivamente são sugestivos da criação de um novo campo do jornalismo na Grécia que se configura como semente de um projeto verdadeiramente radical.

\section{Questões estruturais:}

\section{financiamento e organização}

Uma das principais questões que estes meios de produção noticiosa enfrentam é a sobrevivência, exacerbada neste caso pela profunda crise que assola a Grécia e que constitui uma séria ameaça. Nem todos estes meios de comunicação são sustentáveis e alguns dependem de trabalho voluntário, o que envolve tensão mas também um considerável grau de criatividade. São vários os métodos a que se recorre para gerar receitas e algumas controvérsias também. As principais formas de gerar receitas são: através de donativos e financiamento coletivo (crowdfunding); assinatura ou subscrição; publicidade; através de alguma forma de atividade paralela, por exemplo colaborações internacionais e/ou participações em projetos de investigação. A maior parte destes meios operam como meios de comunicação sem fins lucrativos ou empresas cooperativas (ver também Siapera e Papadopoulou, 2016).

Alguns destes meios têm sido especialmente bem-sucedidos na angariação de financiamento coletivo (crowdfunding). As Infowar Productions, geridas pelo jornalista Aris Chatzistefanou, produziram quatro documentários de grande sucesso todos com base neste tipo de financiamento. O The Press Project lançou um pedido de financiamento coletivo lado a lado com um serviço de subscrição premium, tendo ambos obtido um sucesso razoável. O Efsyn opera como jornal impresso e online, pelo que uma grande parte das suas receitas provém da circulação da versão impressa. Como mencionado na introdução, alguns meios aceitam de bom grado a publicidade mas não sem considerável discussão e tensões. No Efsyn houve longos e acesos debates sobre se deveriam aceitar anúncios de bancos. Apesar do elevado grau de ceticismo de alguns membros, no final o argumento vencedor foi o de que a sobrevivência era imperativa, pelo que aceitariam publicidade de qualquer proveniência mas evitariam em simultâneo qualquer tipo de influência por parte dos anunciantes (entrevista, junho de 2015). Apesar deste relato, os nossos informadores explicaram que de qualquer modo este era um debate irrelevante, já que nenhum banco queria anunciar no seu jornal. Outros meios apenas aceitam anúncios éticos de pequenas empresas. Outros ainda, como o The Press Project, acreditam que qualquer tipo de dependência de receitas 


\section{One of the main}

issues faced by

these media outlets

is survival. This

is exacerbated

because of the deep

crisis in Greece

and it poses $a$

serious threat

\section{Structural issues: funding and organization}

One of the main issues faced by these media outlets is survival. This is exacerbated because of the deep crisis in Greece and it poses a serious threat. Not all of these media are sustainable and some of them rely on volunteer labour. There are tensions involved here but also considerable inventiveness. There are various methods used to generate income and certain controversies as well. The main ways of generating revenue are: through donations and crowdfunding; subscription; advertising; through some form of parallel activity, for example, international collaborations and/or participation in research projects. Most of these media operate as not-for profit media or as cooperative enterprises (see also Siapera and Papadopoulou, 2016).

Some of these media have been remarkably successful in crowdfunding. Infowar Productions, run by the journalist Aris Chatzistefanou has produced four highly successful documentaries all relying on crowdfunding. The Press Project has launched a crowdfunding appeal alongside a premium subscription service, both of which have been reasonably successful. Efsyn operates as a print and online newspaper, so a large part of its revenue comes from its print circulation. As mentioned in the introduction, some media are happy to accept advertisements but not without considerable discussion and tensions. In Efsyn there were long and tense discussions of whether they should accept advertisements from banks. While some members were very sceptical, in the end the argument that won was that survival is imperative, so that they would accept advertisements from anybody but at the same time prevent any influence from advertisers (interview, June 2015). As it happened, our informants told us that this was a moot point anyway, as no bank wanted to advertise with them. Other media would only accept ethical advertisers from small businesses. Yet others, such as The Press Project, believe that any kind of reliance on income from advertising may compromise their independence. Next to from crowdfunding and advertising, collaboration with other, bigger media 
de publicidade pode comprometer a sua independência. Seguindo de perto o financiamento coletivo e a publicidade, a colaboração com outros meios de comunicação de maiores dimensões ao nível nacional e internacional também foi considerada como opção para angariação de fundos por alguns dos nossos entrevistados. Por exemplo, a Infowar colaborou com o The Guardian, enquanto o Alterthess colaborou com a Sto Kokkino, uma agência noticiosa pertencente ao Syriza (rádio e online). A Radiobubble colaborou com outros jornalistas europeus na produção de uma série sob o título "The Migrant Files" cofinanciada pelo Fundo de Jornalismo sem fins lucrativos (http:// journalismfund.eu). A série "The Migrant Files" venceu o prémio de jornalismo de dados de 2014 (http://www.rbdata.gr/themigrantsfiles).

Apesar de não haver uma receita única que sirva a todos nem, certamente, nenhuma receita mágica no que concerne ao financiamento, existe uma linha comum em todos os esforços de angariação de fundos: a da transparência. Todos os nossos informadores insistiram que esta é a única forma que lhes permite convencer os leitores de que são diferentes de outras fontes e a única através da qual conseguem criar e manter confiança e credibilidade. Independentemente da proveniência, eles têm de ser abertos e transparentes no que se refere às suas receitas.

Em termos de organização da redação, na maioria existem estruturas de redação abertas com filosofias de funcionamento claras, que estão subjacentes à forma como operam e às decisões tomadas ao nível editorial. Estas filosofias desenvolvem-se à volta de três posições principais. Em primeiro lugar, operam na base de uma agenda progressiva - por exemplo, um dos nossos informadores referiu explicitamente a necessidade de fazer face ao défice democrático na Grécia e noutros locais (Infowar, entrevista, 21/5/2014). Em segundo, estão firmemente orientados para a própria sociedade e movidos pelas suas necessidades - neste sentido, não cobrem necessariamente as típicas notícias do parlamento, tribunais e outros, mas têm os olhos e ouvidos firmemente postos na sociedade. Em terceiro, autorregulam-se com base numa cultura comum que se desenvolveu de forma orgânica através de discussões e troca de argumentos e através de feedback dos leitores e colegas.

Isto traduz-se em várias práticas. Para os meios de maior dimensão, como o Efsyn, a tomada de decisão tem lugar através de discussões tipo assembleia. Algo que também é comum em meios mais pequenos, como o The Cricket. Noutros casos os editores podem assumir a decisão final, mas com base nas filosofias acima. Os repórteres sugerem áreas ou histórias que consideram que deviam cobrir e discutem com os restantes se as deveriam seguir de forma prioritária ou se deveriam dar precedência a outros tópicos. Em alguns contextos, por exemplo no Radiobubble e no The Cricket, os jornalistas escolhem livremente as notícias, perspetivas e tópicos para investigar e escrever, já que "ninguém lhes diz o que devem fazer" (Cricket, 16/7 2015). Os casos de disputa ou desacordo são resolvidos através de discussões: "Discutimos, discordamos, concluímos, acordamos" (Radiobubble, 10/10/2013). Se necessário, qualquer censura provém dos pares/leitores: no caso de uma reportagem ou artigo de opinião não ser considerado muito bom ou adequado, espera-se que os leitores comentem, solicitem alterações ou até a sua retirada - apesar de se dever dizer que tal nunca aconteceu, o que, por sua vez, implica um bom nível de coesão na redação. 
either national or international was also seen as a funding option by some of our respondents. For example, Infowar has collaborated with The Guardian, while Alterthess collaborates with Sto Kokkino, a Syriza-owned news outlet (radio and online). Radiobubble collaborated with other European journalists to produce a series of articles under the title The Migrant Files co-funded by the non-profit Journalism Fund (http://journalismfund.eu). The Migrant Files won the data journalism award of 2014 (http://www.rbdata.gr/ themigrantsfiles).

While there is no one-size fits all and certainly no magical solutions when it comes to funding, there is one common line across all money-raising efforts: that of transparency. All our informants insisted that this is the only way in which they can convince readers that they are different from other sources of media and the one way in which they can build and sustain trust and credibility. No matter where their income comes from therefore, they have to be open and transparent about it.
When it comes to newsroom organisation, for the most part there are open newsroom structures with clear operational philosophies, that underpin both the way they operate and their editorial decision making. These philosophies revolve around three main positions. Firstly, they operate on the basis of a progressive agenda - for example, one of our informants explicitly referred to the need to address the democratic deficit in Greece and elsewhere (Infowar, interview, 21/5/2014). Secondly, they are firmly oriented towards society itself, and driven by its needs - in these terms, they would not necessarily cover beats such as the parliament, courts and so on, but they have their eyes and ears firmly turned towards society. Thirdly, they are self-regulating on the basis of a common culture that has evolved organically, through discussions and exchange of arguments, and through feedback from readers and colleagues.

These translate to several practices. For the larger media, such as Efsyn, decision-making takes place through assembly-style discussions.
This is common in some smaller media as well, such as The Cricket. In other instances, editors may take the final decision, but on the basis of the above philosophies. Reporters suggest areas or stories they think they should cover and then discuss with everyone else whether they should follow them as a matter of priority or whether other themes should be given precedence. In some contexts, for example, in Radiobubble and in The Cricket, journalists freely choose news, views and topics to research and write about as "nobody will tell them what to do" (Cricket, 16/7 2015). Cases of disputes or disagreements are dealt with through discussion: "we discuss, we disagree, we conclude, we concur" (Radiobubble, 10/10/2013). If necessary, any censure will come from peers/readers: if an article or opinion article is not seen as very good or appropriate, readers are expected to comment, request amendments or even withdrawal- although it has to be pointed out that this has never happened, which in turn implies a good level of cohesion in the newsroom. 


\section{Conteúdo: Os temas do jornalismo radical}

As diferentes estruturas destes meios aludem a uma perspetiva e abordagem diferentes das notícias. Para todos os meios de comunicação aqui analisados o principal valor da notícia é: o que a sociedade quer e/ou precisa? Dar prioridade às necessidades da sociedade é um imperativo, o que deixa por outro lado em aberto a questão de quem determina quais são essas necessidades. Nos meios de comunicação sob estudo isto é facilmente resolvido através da análise dos meios de comunicação convencionais e da colocação de duas questões: o que é que os meios de comunicação convencionais não cobrem? Como é que os meios de comunicação convencionais cobrem a matéria? Usando isto como ponto de partida, os meios radicais tentam ainda incluir múltiplas perspetivas e várias vozes. Tanto o Efsyn como a Omnia TV, por exemplo, permitem uma variedade de vozes ao oferecer aos jornalistas uma plataforma para escrever artigos de opinião ou, no caso da Omnia, para produzir vídeos sobre qualquer tema. No entanto, esta polifonia tem de seguir determinadas orientações. Por exemplo, a Omnia especifica que quaisquer "conteúdos ofensivos, enganosos, pornográficos, incorretos, ou conteúdos que promovam qualquer tipo de discriminação (racismo, xenofobia, islamofobia, antisemitismo, homofobia, transfobia e outras) serão transferidos para a respetiva categoria dentro da grande categoria de conteúdos "Censurados", acessível apenas a utilizadores registados [...]" (https://omniatv. com/terms). Desta forma excluem materiais considerados ofensivos, racistas ou inapropriados mas de uma forma transparente e sujeita a verificação por parte da comunidade que gere e participa na Omnia.

Em termos dos temas ou tópicos específicos, as preocupações societais são a principal prioridade e quaisquer reportagens sobre o processo político formal interrelacionam-se com as respetivas preocupações societais. Exemplos de tópicos cobertos incluem a controversa mina de ouro em Skouries, no norte da Grécia, um tópico totalmente ignorado pelos meios de comunicação convencionais; a VIO.ME, uma fábrica ocupada e autogerida e outras iniciativas cooperativistas semelhantes; repressão policial, solidariedade para com os refugiados e antirracismo; o julgamento do Golden Dawn (o partido político fascista-racista); o encerramento de serviços públicos, as privatizações e o seu impacto na sociedade e o desemprego, entre outros.

Enquanto alguns destes tópicos também foram cobertos por alguns meios de comunicação tradicionais, o tom e tipo de cobertura é muito diferente: é dada prioridade às vozes dos que foram afetados, há a preocupação de evitar sensacionalismos e pensar no impacto da reportagem sobre os afetados; há em geral muito mais tempo, pensamento e esforço despendidos nesses tópicos. Algumas destas iniciativas também se encontram ativamente envolvidas na produção de novos tipos de escrita jornalística, incluindo multimédia, com ênfase nas experiências estéticas dos leitores/utilizadores, bem como em reportagens baseadas em dados. Alguns, como por exemplo a Radiobubble, procuram igualmente criar novas formas inovadoras de jornalismo social, através da promoção de uma hashtag do Twitter (\#rbnews) para peças de jornalismo cidadão. Isto, segundo eles, constitui uma experiência social única na transição de um jornalismo cidadão para um novo estado jornalístico, usando 


\section{Substance: The topics of radical journalism}

The different structures of these media allude to a different perspective and approach to the news. For all the media under study here, the main news value is: what does society want and/or need? Prioritising society's needs is imperative, but on the other hand it begs the question of who determines what these needs are. For the media under study here this was easily resolved by looking at the mainstream media and posing two questions: what do mainstream media not cover? How do the mainstream media cover it? Using this as a point of departure, radical media also strive to include multiple perspectives and many voices. Both Efsyn and Omnia TV for example allow a variety of voices by offering journalists a platform to write opinion articles or in the case of Omnia, to produce video stories on any topic. However, this polyphony has to follow certain guidelines. For example, Omnia specifies that any "offensive, misleading, pornographic, inaccurate contents, or contents that promote discrimination (racism, xenophobia, islamophobia, antisemitism, homophobia, transphobia and so on) will be moved to a corresponding category under the (broader category) 'Censored', accessible only to registered users [...]" (https://omniatv.com/terms). In this manner, they exclude materials deemed offensive, racist or inappropriate but in a transparent manner and subject to checks by the community that runs and participates in Omnia.

In terms of the specific themes or topics, societal concerns are the main priority, and any reports on the formal political process are in connection with corresponding societal concerns. Examples of topics followed include the controversial goldmine in Skouries in Northern Greece, a topic all but ignored by mainstream media; VIO.ME, an occupied and self-managed factory, and other similar cooperative initiatives; police repression, solidarity to refugees, and anti-racism; the trial of the Golden Dawn (the fascist-racist political party); closure of public services, privatisations and their impact on society; unemployment and so on.
While some of these topics are also covered by some mainstream media, the tone and style of coverage is very different: priority is given to the voices of those affected, there is concern to avoid sensationalism and to think of the impact of reporting on those affected; and in general there is much more time, thought and effort spent on these topics. Some of these initiatives are also actively involved in producing new kinds of journalistic writing, including multimedia and an emphasis on the aesthetic experiences of readers/users, as well as reporting using data. Some, for example Radiobubble, are also seeking to create innovative new forms of social journalism, through curating a Twitter hashtag (\#rbnews) for citizen journalism. This, as they put constitutes a unique social experiment for the transition from a citizen journalism to a new journalistic polity, using a curated hashtag for news (not views or opinions) that is accurate, verified and checked (http://international.radiobubble.gr/p/pl.html)

At the level of substance, therefor, there are fundamental changes in the themes/topics covered, in the time 
uma hashtag aprovada para notícias (não perspetivas ou opiniões) que é precisa, verificada e aprovada (http://international.radiobubble.gr/p/pl.html)

Em termos de substância, consequentemente, existem mudanças significativas nos temas/tópicos abordados, no tempo despendido e na profundidade dos relatos noticiosos, nas vozes que são deixadas transparecer e na forma como as histórias são difundidas. Existe uma viragem clara no sentido da própria sociedade em toda a sua multiplicidade e complexidade e uma clara mudança nos valores e hierarquias das notícias passando da cobertura de elites para a cobertura de notícias e assuntos que importam à sociedade através do recurso a formas inovadoras de os relatar.

\section{Subjetividade: a criação de uma nova identidade profissional}

Um dos aspetos mais notáveis desta forma de jornalismo é o de que na sua maioria é produzido por jornalistas profissionais que já trabalharam anteriormente em meios de comunicação convencionais e/ou que têm formação na área do jornalismo. No entanto, as suas identidades jornalísticas foram radicalizadas tanto ao nível político como profissional. Os produtores deste tipo de jornalismo são jornalistas profissionais. A radicalização política gira em torno de ideais de comum, de propriedade pública, de social (ou aquilo que se cria entre as pessoas) e de sociedade (a parte já formada de grupos, comunidades e outros). A radicalização política não chegou de repente, antes pelo contrário podem identificar-se as suas ondas sucessivas. A primeira foi em 2008, nos motins de dezembro, no seguimento do homicídio de Alexis Grigoropoulos por um polícia no bairro de Exarcheia. A Radiobubble e a hashtag \#rbnews emergiram nessa altura, explicitamente como forma de contrariar a cobertura enganosa e sensacionalista dos meios de comunicação convencionais. Este foi um dos primeiros momentos em que o público, e especialmente aqueles que viveram os eventos dos motins, os jornalistas/trabalhadores dos meios de comunicação social, se aperceberam de que os meios tradicionais não podem ou não querem sentir o pulsar da sociedade e que urge iniciar um projeto jornalístico alternativo (ver também Metropolitan Sirens, 2011). A segunda onda teve lugar durante o movimento das praças, no verão de 2011, em que as pessoas começaram a ocupar espaços públicos e a fazer exigências. Os jornalistas que tinham sido despedidos, que tinham passado por encerramentos súbitos dos meios onde trabalhavam, ou a quem foi dito sobre o quê e como deveriam escrever, começaram a aperceber-se de que existiam outras possibilidades para além dos meios convencionais. Outra onda de jornalismo radicalizado emergiu após o encerramento da emissora de serviço público no verão de 2013, seguida por uma longa ocupação dos estúdios e escritórios por funcionários despedidos. $\mathrm{O}$ emergir de uma outra onda pode ser percebido na sequência do gritante partidarismo dos meios de comunicação convencionais e especialmente a televisão no período que antecedeu o referendo de 2015, num claro desrespeito pelo seu próprio código ético (Pleios, 2015). Estes eventos políticos tiveram um grande impacto na forma como os jornalistas entendem o seu 
spent and depth of the news reports, in the voices allowed to be heard, and in the ways in which stories are put across. There is a clear turn towards society itself in all its multiplicity and complexity, and a clear shift in the news values and hierarchies, from covering elites to covering news and issues that matter to society using innovative forms of storytelling.

\section{Subjectivity: \\ the creation of a new professional identity}

One of the most notable aspects of this form of journalism is that in its majority it is produced by professional journalists who have worked for mainstream media and/or who have journalistic training. However, their journalistic identities have become radicalised in both political and professional terms. he producers of this journalism are professional journalists. The political radicalisation revolves around ideas of the common, public property, the social (or what is created between people) and society (the already formed part of groups, communities and so on).
Political radicalisation didn't come at once but can be traced in successive waves. The first one was in 2008 , in riots of December, following the police murder of Alexis Grigoropoulos in the Exarcheia neighbourhood. Radiobubble and the \#rbnews hashtag emerged at the time, explicitly as a means of countering the misleading and sensationalist coverage of mainstream media. This was one of the first clear realisations both by the public, and especially those who lived the event of the riots, and by journalists/media workers that mainstream media cannot or do not want to grasp the pulse of society and that an alternative journalistic project needs to be started (see also Metropolitan Sirens, 2011). The second wave took place during the movement of the squares, in the summer of 2011, where people began occupying public spaces and formulating demands. Journalists who had by then been laid off, lived through sudden media closures or told what and how to write, began to realize that there are other possibilities beyond the mainstream media. Another wave of radicalised journalists emerged after the closure of the public service broadcaster in the summer of 2013, followed by a long occupation of the studios and offices by laid off workers. Yet another wave can be seen as having emerged out of the blatant partisanship of the mainstream media and especially television in the period before the referendum of 2015, which were clearly breaching their own code of ethics (Pleios, 2015). These political events have had a big impact on the ways in which journalists understand their political role, and contributed to a radical shift of their perception of their identity.

In professional terms, they formulated as their main value and priority to serve society and to be part of society, rather than serving interests of particular social classes, of their employers, or political parties. This was more clearly shown in the case of ErtOpen which emerged in the days of occupation of the public service broadcaster's studios. ErtOpen sought to reclaim and reimagine public service broadcasting outside of state pressures and using societal needs as a pivot. In ErtOpen, the needs of those who suffer are prioritised often at the expense of journalists' own needs, as witnessed by the long hours spend volunteering.

At the subjective level we observed a combination of strong professional 
papel político e contribuíram para uma mudança radical na perceção da sua identidade.

Em termos profissionais eles formularam como principal valor e prioridade o serviço à sociedade e fazer parte da sociedade, não o serviço de interesses de classes sociais particulares, seus empregadores ou partidos políticos. Isto ficou claramente demonstrado no caso da ErtOpen, que surgiu nos dias de ocupação dos estúdios da emissora do serviço público. A ErtOpen procurou reclamar e re-imaginar a emissão de serviço público à margem das pressões estatais usando o enfoque nas necessidades da sociedade. Na ErtOpen, dá-se prioridade às necessidades dos que sofrem frequentemente à custa das "próprias necessidades" dos jornalistas, como demonstram as longas horas de trabalho voluntário.

Ao nível subjetivo observámos uma combinação de fortes valores profissionais e ética, como por exemplo o enfoque numa escrita de qualidade, precisão da informação apresentada, verificação dos factos, relatos criativos, investigação e outros, com uma viragem para a sociedade. Não se trata aqui do jornalismo liberal do desprendimento, mas de um jornalismo do apego. Os jornalistas percebem-se como parte da sociedade, não como observadores externos. Para a maioria dos nossos informadores seguir este processo de radicalização implica que não há retorno e isto foi referido explicitamente. De facto, quando a ERT foi reaberta pelo primeiro governo do Syriza a maioria dos que estiveram ativamente envolvidos na ocupação e no ErtOpen recusaram-se a regressar devido à nova emissora não ter cumprido o seu mandato uma vez que o governo começou a fazer nomeações estratégicas e a evitar emitir orientações claras que salvaguardassem os jornalistas da ingerência estatal. É evidente que se levantam questões e tensões, uma vez que é frequente os jornalistas terem de enfrentar graves dificuldades financeiras, mas mesmo assim preferem não ceder. "Temos de conseguir sobreviver, mas não estamos nesta profissão pelo dinheiro" (Infowar, entrevista, 2014). Em retorno, a maioria dos jornalistas refere um sentimento de orgulho por terem sido capazes de recuperar o respeito da sociedade.

\section{Nível relacional: reposicionar o jornalismo}

Muito foi feito relativamente à autonomia do jornalismo e à separação do campo do jornalismo de outras áreas da sociedade (p. ex. Bourdieu, 1999). Bourdieu (1999), assim como Habermas (1996), defendem que o jornalismo deve manter a sua autonomia relativamente à sociedade, à política e ao mercado, de modo a poder desempenhar bem o seu dever. Na obra "Facts and Norms" (1996) Habermas argumenta que o jornalismo deveria agir como o sistema judicial e, na verdade, o entendimento do jornalismo como quarto poder aponta para uma elevação e separação semelhante do jornalismo relativamente a outras esferas. Habermas descreve esta perspetiva normativa de forma muito clara: defende ele que os jornalistas "devem entender-se como mandatários de um público esclarecido cuja predisposição para aprender e capacidade de crítica devem imediatamente assumir, exigir e reforçar; à semelhança do sistema judicial, eles devem preservar a sua independência de pressões políticas e sociais; devem estar recetivos às preocupações e propostas do público, 
values and ethics, for example, emphasis on good writing, accuracy of the information presented, verification of facts, imaginative storytelling, research and so on, with a turn towards society. This is not the liberal journalism of detachment but a journalism of attachment. Journalists perceive themselves as part of society, not as observers from the outside. For most of our informants, following this process of radicalisation there is no going back, and this was explicitly stated. Indeed, when ERT reopened by the first Syriza government, most of those actively involved in the occupation and in ErtOpen refused to go back, because the new broadcaster did not fulfil their remit as the government began making strategic appointments and avoiding clear guidelines to safeguard journalists from state interference. Clearly, there are difficulties and tensions involved, as often journalists face severe financial hardship - but they still would not compromise. "We want to be able to survive, but we are not in this for the money" (Infowar, interview, 2014). As payback, journalists often referred to a sense of pride because they have regained society's respect.

\author{
At the same \\ time, radical \\ journalism rejects \\ any separation \\ from society and \\ is very sceptical \\ to any notion of \\ impartiality
}

\section{Relational level: relocating journalism}

Much has been made about the autonomy of journalism, and the separation of the field of journalism from other fields of society (e.g. Bourdieu, 1999). Bourdieu (1999) as well as Habermas (1996) hold that journalism must remain autonomous from both society and politics, as well as from the market, in order to be able to perform its duties. In Facts and Norms (1996) Habermas makes the argument that journalism ought to act as the judiciary, and indeed understandings of journalism as the fourth Estate point to a similar elevation and separation of journalism from other spheres. Habermas articulates this normative perspective very clearly: journalists he argues, "ought to understand themselves as the mandatary of an enlightened public whose willingness to learn and capacity for criticism they at once presuppose, demand, and reinforce; like the judiciary, they ought to preserve their independence from political and social pressure; they ought to be receptive to the public's concerns and 
Figura 1. Relação do jornalismo com a sociedade e a política no jornalismo convencional e radical

Relationship of journalism to society and journalism politics in mainstream and in radical

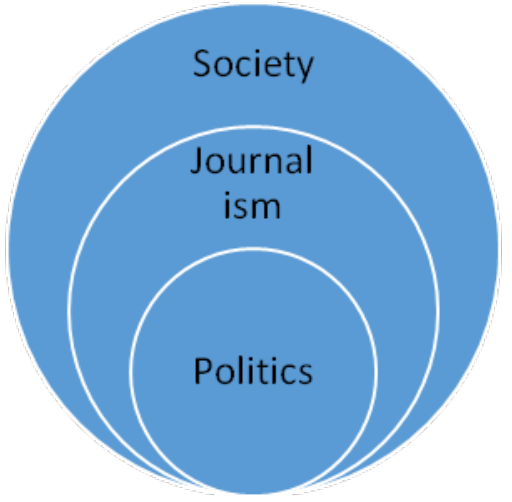

Se tivéssemos de representar estomar essas questões e contributos de forma imparcial, aumentar as críticas e confrontar o processo político com exigências articuladas de legitimidade". (1996: 378). Mas nas condições da pós-democracia tal legitimação não é necessária nem desejável, uma vez que legitimar a pós-democracia significaria aceitá-la; isto não deve ser entendido como se os jornalistas radicais não confrontassem o processo político. A confrontação assume a forma de exposição da falta de legitimidade e défice democrático. Simultaneamente, o jornalismo radical rejeita qualquer separação da sociedade e é muito cético relativamente a qualquer noção de imparcialidade. Isto torna-se claro nos temas selecionados e na orientação geral deste tipo de jornalismo. Por exemplo, na cobertura da situação da mina de ouro de Skouries, que foi causadora de destruição ambiental em larga escala, e onde os protestantes foram violentamente atacados pela polícia em diversas ocasiões, enquanto os meios de comunicação convencionais permaneceram calados, a questão da imparcialidade nem se põe: o jornalismo radical coloca-se de forma aberta e inequívoca do lado da sociedade que está a sofrer. quematicamente esta relação seria algo semelhante a um conjunto de círculos sobrepostos, em oposição ao modelo hierárquico que podemos associar ao jornalismo convencional. A Figura 1 sugere um esquema desse tipo.

Por outras palavras, o jornalismo radical acompanha de perto o processo político ao nível local, nacional e europeu, não de forma a legitimá-lo mas para criar ligações entre este processo e as experiências diárias vividas pelas pessoas. Neste sentido, este tipo de jornalismo está a "servir o público", mas um público não concebido no sentido liberal de agregação de indivíduos: um público definido pela comunhão de experiências. A sua relação com a sociedade envolve o alargamento do apoio, solidariedade e cuidado que lhe dão (ver também, Siapera e Iliadi, 2015). Os próprios públicos apoiam e apreciam este tipo de jornalismo, como se depreende no aumento da circulação do Efsyn, nas visitas e "gostos" nas páginas das redes sociais de iniciativas como as da Omnia TV ou do Kollect e nos esforços de angariação de financiamento coletivo (crowdsourcing) do The Press

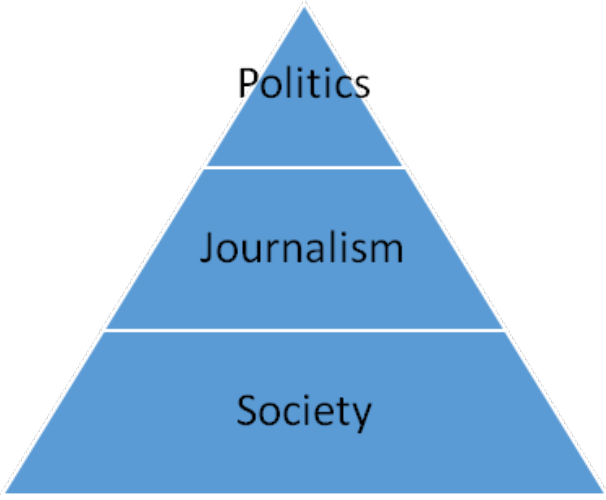

Project. Como um dos entrevistados do Efsyn refere, "sentimos que eles [os leitores] nos apoiam". Dando outro exemplo, o nosso informador do Alterthess disse-nos que uma vítima do ataque homofóbico por fascistas na cidade de Salónica os contactou a pedir ajuda e apoio e que eles o ajudaram a encontrar um advogado e foram com ele à polícia reportar o crime. Esta história é indicativa do tipo de relação desenvolvida entre o jornalismo radical e o público.

\section{Conclusões}

Traçando os contornos de um novo tipo de jornalismo na Grécia atingida pela crise, este capítulo tentou identificar o modo como o jornalismo radical se compreende e opera num contexto que pode ser descrito como pós-democrático. Em simultâneo, o capítulo pretendeu avançar os debates sobre o jornalismo radical e alternativo a partir da análise de iniciativas localizadas de pequena dimensão centradas em políticas "prefigurativas". A atual situação histórico-política da Grécia criou um conjunto quase único de circunstâncias, 
proposals, take up these issues and contributions impartially, augment criticisms, and confront the political process with articulate demands for legitimation." (1996: 378). But in the conditions of post democracy such legitimation is neither necessary nor desirable, since to legitimise post democracy would mean to accept it; this should not be taken to mean that radical journalists are not confronting the political process. Rather the confrontation takes the form of exposing its lack of legitimacy and its democratic deficit. At the same time, radical journalism rejects any separation from society and is very sceptical to any notion of impartiality. This is clear in both the themes selected and the overall orientation of this journalism. For example, covering the goldmine in Skouries, which has been the cause of massive environmental destruction, and where protesters have been violently attacked by the police in numerous occasions, while mainstream media have been silent, the question of impartiality does not arise: radical journalism is siding openly and unequivocally with the parts of society that suffer.
If we were to render schematically this relationship, it would approximate an overlapping set of cycles as opposed to hierarchical model we can associate with mainstream journalism. Figure 1 suggests such as scheme.

In other words, radical journalism monitors closely the political process at the local, national and EU levels, not in order to legitimise them but in order to create connections between this process and the everyday, lived experiences of people. In this sense, this kind of journalism is 'serving the public', but a public not conceived in the liberal sense of aggregates of individuals: a public defined by the commonality of experience. The relationship they have with society is one in which they extend support, solidarity and care (see also, Siapera and Iliadi, 2015). Publics themselves support and appreciate this kind of journalism, as evidenced in the rise in the circulation of Efsyn, in the visits and likes of social media pages of initiatives such as Omnia TV or Kollect, and in the crowdsourcing efforts of The Press Project. As one of the Efsyn respondents put it, "we feel that they [the readers] have our backs". In another example, our informant from Alterthess told us that a victim of a homophobic attack by fascist in the city of Thessaloniki called them to ask for help and support and they then helped him find a solicitor and went with him to the police to report the crime. This story is indicative of the kind of relationships fostered between radical journalism and the public.

\section{Conclusions}

Tracing the contours a new kind of journalism in crisis-stricken Greece, this chapter attempted to identify how radical journalism understands itself and operates in the context that can be described as post democracy. At the same time, the chapter wanted to move on from discussions of radical and alternative journalism from contemplating small, localised initiatives focusing on 'prefigurative' politics. The current historico-political situation in Greece has created an almost unique set of circumstances, including 
incluindo as esferas desacreditadas dos meios de comunicação convencionais e política pós-democrática ilegítima, que permitiram o desenvolvimento de uma nova forma de jornalismo radical que já não se encontra confinado às margens mas que se torna cada vez mais parte do centro. Neste sentido, este jornalismo radical procura reclamar o convencional em vez de se opor a ele. A este respeito é semelhante ao movimento das praças que teve lugar na Grécia há alguns anos: em vez de se confinar a zonas e protestos marginais este novo jornalismo pugna pela radicalização do convencional.

$\mathrm{O}$ jornalismo pode ser visto como uma espécie de termómetro social, sendo que mesmo na suas vertentes mais convencionais continua a ter de sentir o pulsar da sociedade. Enquanto a maioria dos meios de comunicação social da Grécia falharam consegui-lo, aumentando o fosso entre o jornalismo e a sociedade, o novo jornalismo aqui analisado é produzido e opera no seio da crise com vista a criticá-lo e "desmantelá-lo" (Koselleck, 2000 [1988]) utilizando simultaneamente a crise/crítica como conector e gerador de novas ideias (Latour, 2004). Koselleck mostra especificamente como a crítica e o conhecimento desmascararam o rei mostrando-o como homem, enquanto para Latour a crítica é o meio que permite expor a forma como as coisas se agregam dando assim origem a novos laços. Este novo jornalismo radical, nascido da crise e operando como crítica pode, assim, ser visto como um jornalismo da praxis ou do fazer: daí o seu enfoque ser mais na construção ou restabelecimento de relações sociais do que na legitimação das já existentes, como é o caso do jornalismo liberal.

Que lições podemos aprender com este tipo de jornalismo? De uma perspetiva de política radical, o papel político do jornalismo está há demasiado tempo ligado a um entendimento Gramsciano da hegemonia e o papel dos intelectuais que agitam e persuadem. $\mathrm{O}$ surgimento de um novo jornalismo radical em condições de crise significa uma relação mais fundamental e orgânica do jornalismo com a sociedade exigindo mais do que agitprop. Os jornalistas radicais não procuram liderar, agitar ou reportar de forma desconexa da sociedade. Podemos argumentar que, pelo contrário, eles estão envolvidos naquilo que Latour denomina "questões de interesse": em linha com a injunção de Latour no âmbito da ciência, o jornalismo não irá conseguir resolver os problemas do mundo se tratar apenas das questões de facto mas sim começando pelas questões de interesse.

Finalmente importa clarificar que este capítulo escolheu lançar um olhar de esperança sobre este jornalismo. No entanto, os problemas e tensões abundam. Questões de sustentabilidade, a depleção de energias, especialmente após o recuo do Syriza, aumentando a frustração, estão a abalar este jornalismo, à medida que a agressão contra a sociedade grega continua. $\mathrm{O}$ ambiente não é de harmonia e homogeneidade mas antes um ambiente caraterizado por relações antagonísticas (ainda que igualmente sinergéticas); alguns meios estão mais próximo de conceções liberais convencionais do jornalismo enquanto outros se orientam quase exclusivamente no sentido de enclaves radicais. Em vez de nos focarmos nas tensões e problemas, procurámos centra-nos naqueles elementos que configuram sementes de algo esperançoso e promissor. Continuaremos à espera que a promessa contida neste tipo de jornalismo seja cumprida. 
the discredited spheres of mainstream media and illegitimate post democratic politics, which allowed for the development of a new form of radical journalism that is no longer confined in the margins but is becoming increasingly part of the centre. In this sense, this radical journalism is looking to reclaim the mainstream rather than opposing it. In this respect it is similar to the movement of the squares that took place in Greece a few years ago: rather than been confined to marginalised areas and protests, this new journalism is striving for the radicalization of the mainstream.

Journalism can be seen as a kind of social thermometer, because even in its mainstream guise it still needs to feel the pulse of society. While most mainstream media in Greece have failed to do this, widening the chasm between journalism and society, the new journalism traced here is produced by and operates within this crisis with a view to critique and 'dismantle' it (Koselleck, 2000 [1988]) but also in using the crisis/critique as a connector and generator of new things (Latour, 2004). Specifically, Koselleck showed how the critique of the enlightenment unmasked the king as man while for Latour critique is the means that can expose how things are held together, thereby leading to the creation of new bonds. This new radical journalism born of the crisis and operating as critique can therefore be seen as a journalism of praxis or doing: this is why the emphasis is more on building or restoring social relationships, rather than in legitimising existing ones as in the case of liberal journalism.

What are the lessons that we can learn from this kind of journalism? From a radical politics point of view, journalism's political role far too long annexed to a Gramscian understanding of hegemony and the role of intellectuals who agitate and persuade. The rise of a new radical journalism in conditions of crisis signifies a more fundamental and organic relationship of journalism to society that requires more than agit prop. Radical journalists are not seeking to lead or to agitate or to report disconnected from society. Rather we can argue that they are involved in what Latour refers to as 'matters of concern': much like Latour's injunction for science, journalism cannot solve the world's problem by attending to matters of fact, but rather by beginning from matters of concern.

Finally, it should be made clear that this chapter chose to cast a hopeful eye to this journalism. Problems and tensions however abound. Questions of sustainability, the depletion of energies, especially following Syriza's U-turn, increasing frustration are undermining this journalism, as the assault against society in Greece continues. The field is not a harmonious, homogenous one, but one characterised by antagonistic (but also synergistic) relationships; some outlets are closer to mainstream liberal conceptions of journalism while others are oriented almost exclusively towards radical enclaves. But rather than focusing on the tensions and problems, we sought to focus on these elements that contain the grains for something hopeful and promising. And we will keep on hoping that the promise entailed in this kind of journalism will be fulfilled. 


\section{Bibliografia/ References}

Atton, C. \& Hamilton, J.F. (2008). Alternative journalism. Sage.

Atton, C. (2002). News cultures and new social movements: Radical journalism and the mainstream media. Journalism Studies, 3(4), 491-505.

Bailey, O., Cammaerts, B. \& Carpentier, N. (2007). Understanding alternative media. McGraw-Hill Education (UK). Fenton.

Bourdieu, P. (1998). On Television and Journalism. Pluto Press.

Couldry, N. \& Curran, J. (Eds.) (2003). Contesting media power: Alternative media in a networked world. Rowman \& Littlefield Publishers.
Couldry, N. (2000). The place of media power: Pilgrims and witnesses of the media age. Psychology Press.

Couldry, N. (2002). Mediation and alternative media, or relocating the centre of media and communication studies. Media International Australia incorporating Culture and Policy, 103(1), 24-31.

Crouch, C. (2004). Post-democracy. Cambridge: Polity.

Crouch, C. (2011). The strange non-death of neo-liberalism. Polity.

Downing, J.D. (2000). Radical Media - Rebellious Communication and Social Movements: Rebellious Communication and Social Movements. Sage Publications.

Emarketer (2015). Total Ad Spending Remains Flat in Greece - Total ad budgets will sit at $€ 1.10$ billion through 2017. Acedido a 11 de setembro de 2016, em http://www. emarketer.com/Article/Total-Ad-Spending-Remains-Flat-Greece/1012736

Eurobarometer (2015). Standard Eurobarometer 2015, No 84, Report: Media Use in the European Union. Acedido a 11 de setembro de 2016, em https:// www.ebu.ch/files/live/sites/ebu/files/ Publications/EBU-MIS\%20-\%20 Trust\%20in\%20Media\%202016.pdf Habermas, J. (1996). Between Facts and Norms. Polity, Oxford,

Koselleck, R. (2000). Critique and Crisis: Enlightenment and the pathogenesis of modern society. MIT Press.

Latour, B. (2004). Why has critique run out of steam? From matters of fact to 
matters of concern. Critical Inquiry, 30(2), pp.225-248. Acedido a 11 de setembro de 2016, em http://www. bruno-latour.fr/sites/default/files/ 89-CRITICAL-INQUIRY-GB.pdf

Metropolitan Sirens (2011). The (revolt) medium is the message: Counter-information and the 2008 revolt. In D. Dalakoglou \& A. Vardis, (eds), Revolt and crisis in Greece. AK Press \& Occupied London.

Pleios, G. (2013). The crisis and the Greek media, [in Greek]. Efsyn, September 9. Acedido a 11 de setembro de 2016 , em http://archive.efsyn.gr/?p=146285

Pleios, G. (2015). Journalistic code of ethics and Greek media. Presentation of research findings, Oct 22, Athens.

Poulakidakos, S. (2013). Propaganda as a fundamental ingredient of public discourse. The presentation of the "MoU"- bailout agreement by the Greek Media [in Greek], PhD thesis, National and Kapodistrian University of Athens. Acedido a 11 de setembro de 2016, em http://hdl. handle.net/10442/hedi/30053

Rodriguez, C. (2001). Fissures in the mediascape: An international study of citizens'media. Hampton Press (NJ). Siapera, E., Papadopoulou, L. \& Archontakis, F. (2015). Post-Crisis Journalism: Critique and renewal in Greek journalism. Journalism Studies, 16(3), 449-465.

Siapera, E. \& Papadopoulou, L. (2016). Entrepreneurialism or Cooperativism? An exploration of cooperative journalistic enterprises. Journalism Practice, 10(2), 178-195.
Siapera, E. \& Iliadi, I. (2015). Twitter, Journalism and Affective Labour. Sur le journalisme, About journalism, Sobre jornalismo, 4(1), 76-89. 